\title{
CHANGE IN COMMUNICATION MANAGEMENT ROLES DUE TO GLOBALIZATION: A CASE OF COMMUNICATION MANAGEMENT COMPETENCIES MAPPED BY INTERNATIONAL PROFESSIONAL PUBLIC RELATIONS ASSOCIATIONS (2015-2020)
}

\author{
Renata Matkevičiene $\dot{e}^{1, a}$ and Lina Jakučionienè $\dot{2}^{2, b, *}$ \\ ${ }^{1}$ Vilnius university, Faculty of Communication, Lithuania \\ ${ }^{2}$ Vilnius university, Faculty of Communication, Lithuania \\ arenata.matkeviciene@kf.vu.lt, blina.jakucioniene@kf.vu.lt \\ *Corresponding author
}

Cite as: Matkevičienè, R., Jakučionienè, L. (2021). Change in communication management roles due to globalization: A case of communication management competencies mapped by international professional public relations associations (2015-2020), Ekonomicko-manazerske spektrum, 15(2), 6586.

Available at: dx.doi.org/10.26552/ems.2021.2.65-86

Received: 17 May 2021; Received in revised form: 23 September 2021; Accepted: 15 October 2021; Available online: 30 December 2021

\begin{abstract}
:
Research background: The role of communication has now become much more critical than during previous periods, not only to compete with other organisations in the stream of communicating messages but also to develop and implement organisational strategies and support the organisation's top-level managers and decision-makers. The goal of public relations (PR) associations is to develop PR professionals' competencies. Comprehensive research at the European level signals the need for constant improvement of competencies, especially business development and technologies (Zerfass et al., 2020; Adi, 2019). A vast majority of practitioners across Europe highlight the importance of digitalising stakeholder communications and building a digital infrastructure to support internal workflows (Zerfass et al., 2021). However, instead of technical and managerial training, PR practitioners continue to overwhelmingly offer communication training and development opportunities (Tench et al., 2013; Zerfass et al., 2018; MacNamara et al., 2017; Feldman, 2017; The USC Annenberg Centre for Public Relations, 2017; Communicating AI, 2019). There are discrepancies between the perceived importance of competencies and the current qualifications of professionals due to digital transformation and changes impacted by globalisation.

Purpose: To identify changes in PR specialists' competencies due to the impact of globalisation. Methods: Content analysis of information provided in the webpages of international professional PR associations for the period 2015-2020.

Findings and value added: The study results show that professional PR associations do not respond to the challenges of the changing environment in a timely manner by providing training, but present and discuss relevant topics with the help of specialists from other fields while encouraging the sharing of good practices. Such a functioning position occupied by professional PR associations in developing the model of competence for PR specialists reveals
\end{abstract}


Changes in communication management roles due to globalization:

A case of communication management competencies mapped by international professional public relations

associations (2015-2020)

Authors: Renata Matkevičienè, Lina Jakučionienè

that PR associations are engaged in strengthening or maintaining competencies, but not developing them.

Keywords: globalization, digital transformation, communication, public relations, competencies, PR associations

JEL Classification: D83, L84, M39, M53

\section{Introduction}

Major economic, political, technological, social, and cultural changes influence the environment. According to McKinsey Global Institute (Manyika et al., 2017), digital technologies that deliver significant value in society in the context of globalization indicate that millions of people worldwide must improve some of their recent competencies or even change professions. This perspective, linked to changes in labour market processes due to information technology, was confirmed in a World Economic Forum report that by $2025,52 \%$ of all tasks will be performed by artificial intelligence, which currently accounts for $29 \%$ (The Future of Jobs, 2018). According to some researchers, digital technology will eliminate jobs and create new positions (Rajnai and Kocsis, 2017).

In the context of the digital economy, the ongoing transformation in the labour market is contributing towards the disappearance of 'ordinary' jobs and the emergence of 'creative' ones. A report by the Agency for Strategic Initiatives (2015) and the World Bank Group (World Development Report,2016) confirms that in future, key competencies such as adaptation, creative thinking, cross-sectoral communication, the ability to use information technology (IT) systems (i.e. the ability to program IT solutions, robotics knowledge, artificial intelligence, and basic programming skills) will become relevant to all professions. The World Economic Forum report (Realising human potential in the Fourth Revolution, 2017) emphasises that creativity, empathy, and ability to adapt to the environment are the most important qualities of future employees. The job market is way ahead of the ivory tower in emphasising soft skills (Deming,2017). It can be concluded that soft skills, which provide the basis for personal and professional development of professionals and enable them to adapt to new conditions while using new information and communication technologies, are particularly important.

Meanwhile, there is a growing trend that the rapid development of the labour market, with digital technologies increasingly shaping the world, may make it difficult for individuals with narrow competencies to sustain and successfully pursue long-term careers (Realising human potential in the Fourth Revolution, 2017). Piva et al. (2006) note that in the context of technological change, a huge gap is emerging between skilled and unskilled workers. The European Skills and Jobs Survey (Insights into skills shortages and skill mismatch, 2018) shows that around $85 \%$ of all EU jobs need at least basic digital skills. This relates to the rapidly evolving new model of work and employment in the present digital world called the 4th Industrial Revolution (Re-Imagining Work, 2017). According to researchers in the field (Vaseyskaya and Glukhov, 2018; Brambilla and Tortarolo, 2018), this model includes not only opportunities but also risks associated with structural changes in the economy and changing human capital requirements. Technological advances reflect the rapid evolution from traditional to modern social media, big data, artificial intelligence, social boots, and new ways of working, including remote and mobile teams, new business models, and digitization (Tench et al., 2013; MacNamara, 2018b). The gap between the current reality and future intent is broadened and subsequently narrowed through the interaction of new possibilities that the organisation envisions in its virtual world, and the new capabilities it develops in its real world (Liedtka, 
2000). Therefore, the discussion on the challenges of digital transformation in the labour market emphasises the development and implementation of appropriate vocational training and professional development programs (Uslu, 2017), considering future projections, criteria for competence, and qualifications in relevant professional fields.

Current research on the competencies of PR professionals has focused on the skills and competencies required for PR professionals and will be important to achieve such roles in the future.

This is an exploratory study that determines how international professional PR associations present their communication activities online, in response to the challenges of globalisation, in particular, digital transformation, and proposes measures to acquire or strengthen relevant competencies.

The analysis aims to not only identify key professional competencies that are articulated by digital transformation and highlighted by the activities of professional PR associations but also to determine the coherence between the need for competencies and the time-to-market supply of activities aimed at developing, strengthening, and fostering such competencies.

\section{Changing professional PR and the challenges of digital transformation}

Technological advancements have expanded the communications sector over the past 20 years. Moreover, this development has been influenced by various political, economic, social, and cultural changes with both business and non-profit organisations recognising the important role of communication in achieving organizational goals (Tench et al., 2013).

The areas most affected by the present communication environment are the drivers of digitalisation: big data, artificial intelligence, and related factors such as fake news and social boots, as well as social media and its associated digital ethics and importance of visual elements in communication (Zerfass et al., 2016; Zerfass et al., 2017; Zerfass et al., 2018; Zerfass et al., 2019; Zerfass et al., 2020). The Internet and mobilisation of information and communication technologies have made non-manual work increasingly portable and remotely accessible (Schlachter et al., 2018). New technologies penetrating the field of PR are also leading to corresponding changes in communication activities and shaping the need for new competencies expected from PR professionals. Technological competencies have a direct, unconditional impact on firms' innovation performance (Lokshin et al., 2009). Changes in the environment, in addition to the conventional roles of PR professionals and the professional competencies required to perform them, such as media relations, crisis management, reputation maintenance and management, leadership, measuring the effectiveness of communication activities (Global Body of Knowledge (GBOK), in 'The Global Body of Knowledge', 2016) also raise the need for building new competencies. Thus, PR professionals must be strategists, understand the business environment and business models, use the latest technological solutions, be digital literate and manage the opportunities provided by big data to develop future insights and create greater value, as framed in 'The Global Capability Framework (GCF)' for public relations and communication management professionals (Fawkes et al., 2018; MacNamara, 2018a; MacNamara, 2018b; Zerfass et al., 2017; Adi, 2019). Public relations professionals perform a wide variety of tasks, ranging from aligning communication strategies and managing teams or departments to coaching employees in professional communication or advising top managers in decision-making processes (Zerfass et al., 2021).

The ability to cope with the challenges of digital evolution and transformation has been singled out as one of the biggest challenges in communication activities in recent years (Zerfass et al.; 2015; Zerfass et al., 2016; Zerfass et al., 2017; Zerfass et al., 2018; Zerfass et al., 2019). It is evident that the assessment of the importance of individual activities related to digital 
Changes in communication management roles due to globalization: A case of communication management competencies mapped by international professional public relations

associations (2015-2020)

Authors: Renata Matkevičienè, Lina Jakučionienè

transformation and the application of modern information and communication technologies in communication activities, as well as public relations, is changing. A few years ago, the term big data for PR professionals seemed supposedly relevant to informatics or data analysts; however, it has now become an important part of the agenda for PR professionals. Digital competence has identified and defined key competencies that are important and essential everyone in a knowledge-based society (Hegyes et al., 2017). As Adi's (2019) study shows, a vast majority of PR professionals lack the competencies to manage big data and create added value in an organisation's communication in a rapidly changing competitive environment.

According to Zerfass et al. (2020), 81\% of PR professionals expressed the need to develop competencies related to the latest technologies. According to Adi's (2019) study, almost $72 \%$ of communication professionals cite digital literacy as an essential competency, but every other communication specialist does not feel competent in the area of digital literacy (big data analysis and methods) (Zerfass et al., 2020).

Another change that affects the communication today is social media. Based on data from the annual European Communication Monitor (ECM) (Zerfass et al., 2007; Zerfass et al., 2008; Zerfass et al., 2009; Zerfass et al., 2010; Zerfass et al., 2011; Zerfass et al., 2012; Zerfass et al., 2013; Zerfass et al., 2015; Zerfass et al., 2016; Zerfass et al., 2017; Zerfass et al., 2018; Zerfass et al., 2019; Zerfass et al., 2020), the ability to adapt to digital change and use social networks accurately in professional activities are consistently emphasized as one of the most important areas of communication, according to PR professionals.

Although social media platforms are not considered to be a new form of communication, PR professionals are using them actively for some time now. However, due to rapid development, managing social media is posing certain challenges for PR professionals, specifically the need to constantly follow trends and learn and apply new tools in communication.

\section{Peculiarities of the competence framework of PR professionals which highlight the influence of globalization and respond to the challenges of digital transformation as a change agent}

Technological advancements have enabled the emergence of novel business models based on digital platforms (Täuscher and Sven, 2018). The role of digital transformation as a change agent in the field of PR competencies is significant, even though apprehensions about the takeover of digital technologies that could change human activities in the PR domain have not materialised (the PR profession was expected to change in the context of interactivity of web portals, access to information development, and establishment of social media platforms), Major changes can be observed in the analysis of big data perception, processing and proper application, management of social platforms, and information flows in both strategic decision making and planning and communication with various stakeholders that require specific competencies in addition to the conventional skills employed by PR specialists.

Relevant knowledge and professional competencies, required in each profession, are the key elements of sustainable economic growth and development in a globalised economy (Hartog, 1992; Sianesi and Reenen, 2003). Research focuses on general and professional competencies. Analysis of the latter emphasises the relationship between competencies and the productivity they generate (Buchel, 2002). Presently, there is a strong need for new competencies dictated by the factors of globalisation (De la Fuente and Ciccone, 2003), and one of the most important is digital literacy competency, or the ability to use and exercise new technologies effectively (Piva et al., 2005).

The definition of competence includes knowledge, abilities, and values that ensure effective actions in professional or personal areas (Whiddett and Hollyforde, 2008; Delamare et al., 
2005). Some authors tend to expand the concept of competence to include cognitive and social behavioural determinants. Another definition of competence includes learning (e.g. acquisition and application of knowledge and skills and commitment to constant seeking) and communication competencies (personal characteristics and interpersonal skills) (Prandi, 2017). Currently, the ability to adapt to a rapidly changing environment is also emphasised (MacNamara, 2018b). This study is based on an 'integrated' concept of competence (Mulder, 2014) in which general and professional knowledge, including skills, attitudes, and values are applied in professional activities.

A method that identifies the key competencies for PR specialists operating in a rapidly changing work environment is the MAPA (Mission, Accomplishments, Performances, Abilities) framework developed by Hunt (1997). Validation of the outcomes of the MAPA process is based on the agreement of stakeholders on the contribution of skills and abilities that are essential to achieve the agreed 'mission statement'. Application of the MAPA model reveals the interdependence between knowledge, skills, and abilities that are required to achieve various organisational goals. The set of competencies will depend not only on the job activities but also on the organisational goals. Competencies are defined in the detailed descriptions or standards of skills and competencies, which are developed based on the views of employers, practitioners, and academics, are mandatory for specialists in the relevant professional field (Jeffrey and Brunton, 2011). According to Wesselink et al. (2010), competencies required for professional practice should form the basis for competence development, although such competencies may be difficult to define precisely (Hager, 2004). Hunt's (1997) 'achievements' and 'activities' at various levels of specificity capture the integrated knowledge and skills necessary for a specialist in the relevant professional field.

The competencies of PR professionals are defined as specific knowledge (what they should know), skills (what they should be able to do), and abilities (what they should know and how to perform/implement). Professional competencies are certain skills that a person working in the relevant professional field must possess. Communication researchers emphasise that sets of competencies vary for representatives of different levels (from the Global body of knowledge 2016; MacNamara, 2018b).

The Global Alliance of Communication and Public Relations, together with universities, has developed a benchmark skills system (GBOK) and a global capability framework for public relations and communication management professionals (Fawkes et al., 2018), which are the largest systems that define the harmonisation of communication competence standards. They identified the roles of PR professionals and the competencies required to perform each role. The GBOK model is based on the managerial-technical dichotomy of competence (Grunig and Hunt, 1984), which highlights the importance of the role of communication and strategic management (Dozier and Broom, 1995; Grunig and Repper, 1992; White and Dozier, 1992) and emphasises that the technical role of PR specialists must be separated from the managerial one. The approach used by the global capability framework for public relations and communication management professionals (Fawkes et al., 2018) allows the analysis of different communication competencies by assigning them to various roles, that is, depending on technical and managerial roles, the various competencies PR specialists must possess (i.e. at different organisational levels, namely entry-level, senior or executive-level, and top-level).

The need for strategic and technological competencies of PR specialists is determined by the fierce competition in the context of a changing environment. The value of being market-driven is currently unchallenged in companies (Kumar et al., 2000). This correlates with the general labour market trends, emphasising the importance of technological, social, and cognitive skills, including analytics, knowledge of business priorities, and leadership in the context of 
Changes in communication management roles due to globalization: A case of communication management competencies mapped by international professional public relations

associations (2015-2020)

Authors: Renata Matkevičiené, Lina Jakučionienè

environmental transformation (MacCrory et al., 2014; Skill Needs, 2018; Smith, 2017). The need raised by employers for strategic competencies of PR specialists also corresponds to the need expressed by PR specialists themselves. Research emphasises the need for communication to be a part of strategic organizational management (Thøger Christenssen et al., 2013; Grunig, 2006). When a team manager is strategically aligned with the CEO, a team manager's visionary leadership is positively related to team strategic consensus and, subsequently, to team strategic commitment (Ateş et al., 2018). Strategic alignment can lead to the development of sustainable competitive advantage (Amankwah-Amoah et al., 2020). However, linking communication to business strategy remains a major challenge for communication professionals worldwide (ECM, 2007-2018).

The results of a study conducted in 2019 on PR specialist competencies (Adi, 2019) correlate with previous studies both in the labour market (Goos et al., 2014; Getting Skills Right, 2016; Ciolacu et al., 2017) and the field of communication (Tench et al., 2013; Zerfass et al., 2018; MacNamara et al., 2017; Feldman, 2017) that identified the problem of the gap between the need for and responsiveness to relevant competencies.

Adi's (2019) study, compared to the previous studies discussed, is new in that it analyses the gaps in the professional development of PR specialists in organisations and examines the issues of cooperation between inter-institutional (professional PR associations, universities) and business organisations (employers). The study found that specialists working in the field of communication believe that PR associations, universities, employers, and PR specialists themselves are responsible for the qualification and training of PR professionals (Adi, 2019). According to Zerfass et al. (2020), 74\% of PR specialists indicated professional PR associations as being responsible for the development of PR specialist competencies. The research data show that PR specialists, assessing the trends of leadership, strategic management, change, and impact on the field of communication, believe that professional PR associations should be organisations that develop and offer various training and improvement programs for communication practitioners. The data also show that $83 \%$ PR specialists, who hold the position of intermediate PR specialists, point out that the employer is responsible for the development of various education and training programs because the competencies required for employees at this level depend on organisational specifics, nature of work in the organisation, and others specificity factors. Public relations specialists, whose activities are related to the implementation of the respective clearly defined communication functions, consider that the PR specialist is responsible for the task of in-service training, and $84 \%$ of employees in this chain endorse it.

Adi's (2019) research aimed to identify the gaps in the competencies of PR specialists in organisations and the interaction of professional communication associations, universities, and business organisations (employers) in ensuring the professional development and development of communication specialists. MacNamara (2018b) argues that competencies must not only help professionals perform tasks and roles but also support them to adapt to a changing environment and prepare them for future challenges.

The existing literature on the topic of PR specialists' competencies provides an opportunity to discuss three empirical research groups in this field. They are 1) studies on the basis of which professional PR associations (including educational institutions, universities) develop competencies requirement for PR specialists, as defined by the GBOK ; 2) studies expressing employers' requirement for a PR specialist with competencies (The CEO Communications Audit, 2017) and ; 3) studies describing essential PR competencies, changes, and trends (Zerfass et al., 2017; Zerfass et al., 2018; Zerfass et al., 2019; Zerfass et al., 2020; Adi, 2019). 
However, research analysis in this area reveals findings that identify the period required for developing in-service training programs that respond to the needs expressed by PR professionals for missing and essential competencies. Training can improve skills that allow employees to exercise proactive tendencies (Lee et al., 2016). Highly educated managers can resolve unforeseen problems and provide effective solutions with the adoption of management innovation (Khosravi et al., 2019).

This study aims to identify the various competencies of PR specialists that are raised and highlighted by PR associations and changes over time, and it also determines the timescale required to respond to the expressed need for PR specialists.

\section{Methodology}

The purpose of this study is to identify the competencies of PR specialists, who are identified by PR associations and promoted through various events, and the time period required to develop these competencies. The research goal assumes that PR specialists express the need for certain competencies, indicating them as necessary at a certain time; however, if the competencies are related to sudden changes in the environment, a delayed market response to the required competencies is observed. We propose the following research questions (RQ).

RQ1: To identify changes in PR specialists' competencies, identified and promoted by professional PR associations (i.e. to meet the need for relevant competencies identified in various studies).

To answer the research question, previous studies are examined to determine the competencies of PR specialists, and a list of competencies is compiled based on the respective year when the need was identified, while indicating the change in competencies. Based on the $\mathrm{ECM}^{1}$ 2015-2020 survey data, the following competencies were identified by top-level PR specialists selected for the study: linking business and communication strategies, strengthening the role of the communication function in supporting top-management decision making, coping with digital evolution and the social web, building and maintaining trust, matching various needs to address a wider audience and channels with limited resources, dealing with the speed and volume of information flow, using big data and/or algorithms for communication, exploring unique ways of creating and distributing content, dealing with sustainable development, and social responsibility.

Research is also conducted on the webpage content of selected professional PR associations to determine the competencies of PR specialists, as reported by professional PR associations, and competencies based on the relevant events that are organised (training, seminars, conferences).

Data collection aims to compare the balance between the required and expressed competencies, as articulated by PR specialists and provided through various PR events.

It is assumed that the competencies expressed by PR specialists differ from the competencies highlighted and provided during training by professional PR associations.

${ }^{1}$ The European Communication Monitor (ECM), the largest transnational study on strategic communication worldwide, which has been conducted annually since 2007 with more than 30,000 participating communication professionals, has been selected as a source expressing the need for developing competencies identified by communication specialists. Based on this source, the TOP 5 competencies, the need for which is expressed by communication specialists, are studied. The selection criteria of this source is the largest transnational study on strategic communication worldwide. 
Changes in communication management roles due to globalization: A case of communication management competencies mapped by international professional public relations

associations (2015-2020)

Authors: Renata Matkevičienè, Lina Jakučionienè

RQ2: To identify the timescale of activities beginning with the identification of competencies and activities when response to confer those competencies provided.

Activities provided by professional PR associations, such as articles shared on webpages, seminars, trainings, conferences organised by associations or offered by partner institutions or members of associations and seminars, other trainings and conferences, information about courses and study programmes offered at the university and college, recommendations on PR activities, reports on the PR profession, other events, knowledge (theoretical and practical knowledge),skills (training providing specific skills), and practices (including internships and shadowing activities).

It is assumed that PR associations apply various measures for providing professional competencies, depending on the specifics of the expressed competencies, access professional PR associations for specialists, who have missing competencies and are able to share them with others.

RQ3: Identifying and anticipating factors that may affect the discrepancy between required competencies and those conferred by professional PR associations when various activities are applied.

It is believed that data collected after the research enables to predict factors that determine the gap between the expressed competencies required by PR specialists and competencies provided by professional PR associations in their activities.

Research methods: The webpages of selected international PR associations were used for qualitative and quantitative content analysis. Two international professional PR associations (International Public Relations Association ( IPRA] and Global Alliance ( GA] ) were selected to reveal the need to have PR specialists is being met. The selection criteria are: 1) act on a global scale (the network of both PR associations covers all continents); 2) functioning for more than 20 years (IPRA was established in 1955, GA in 1996); 3) performance of both PR associations is based on a Code of Conduct/Ethics (launched in 2011, the IPRA Code of Conduct is an affirmation of professional and ethical conduct by members of the association and recommended to public relations practitioners worldwide; GA first adopted a global standard in the form of a set of principles and statements for the ethical practice of public relations in 2003 and updated this Code in 2018). Data sources: https://www.ipra.org/; https://www.globalalliancepr.org/.

Content analysis sample: During the period between 2015-2020, 428 texts were selected based on the component of competencies indicated in the GBOK (i.e. categories), while determining the presence of these categories (semantic units: words, their compounds, concepts) in the analysed texts. In-vivo coding applied.

\section{Results}

Based on prior research in the field of communication, data were analysed by assigning competencies to PR specialists according to their organisational position, that is, competencies applicable to entry-level specialists, senior and top-level specialists assuming that senior or toplevel PR specialists do not have essential, operational, communication competencies which are typical of lower level or novice professionals.

The predominant competencies of entry-level (beginner or operational level) PR professionals are related to activities that are usually responsible for the following professionals: media relations, internal communication, operational level crisis communication, and event management (see Table 1). 
Table 1: Competencies attributed to beginners or working in the field PR specialists (2015-2020, n-91, data in percentage)

\begin{tabular}{|c|c|c|c|c|c|c|c|c|c|c|c|c|c|c|c|}
\hline & $\begin{array}{l}201 \\
5 \\
\end{array}$ & & $\begin{array}{l}201 \\
6 \\
\end{array}$ & & $\begin{array}{l}201 \\
7 \\
\end{array}$ & & $\begin{array}{l}201 \\
8 \\
\end{array}$ & & $\begin{array}{l}201 \\
9 \\
\end{array}$ & & $\begin{array}{l}202 \\
0 \\
\end{array}$ & & & & \\
\hline & $\begin{array}{l}\text { IPR } \\
\text { A }\end{array}$ & $\begin{array}{l}\mathrm{G} \\
\mathrm{A}\end{array}$ & $\begin{array}{l}\text { IPR } \\
\text { A }\end{array}$ & GA & $\begin{array}{l}\text { IPR } \\
\text { A }\end{array}$ & $\begin{array}{l}\mathrm{G} \\
\mathrm{A}\end{array}$ & $\begin{array}{l}\text { IPR } \\
\text { A }\end{array}$ & GA & $\begin{array}{l}\text { IPR } \\
\text { A }\end{array}$ & GA & $\begin{array}{l}\text { IPR } \\
\text { A }\end{array}$ & GA & $\begin{array}{l}\text { IPR } \\
\text { A }\end{array}$ & GA & Total \\
\hline $\begin{array}{l}\text { Client } \\
\text { management }\end{array}$ & 2,20 & & 1,10 & & 2,20 & & 1,10 & & 2,20 & & 1,10 & 1,10 & 9,89 & 1,10 & 10,99 \\
\hline $\begin{array}{l}\text { Strategic } \\
\text { planning }\end{array}$ & 1,10 & & 3,30 & & 1,10 & & & & 1,10 & $\begin{array}{l}1,1 \\
0\end{array}$ & 1,10 & & 7,69 & 1,10 & 8,79 \\
\hline $\begin{array}{l}\text { PR program } \\
\text { planning }\end{array}$ & & & & & & & 1,10 & & 1,10 & & & & 2,20 & 0,00 & 2,20 \\
\hline $\begin{array}{l}\text { Media } \\
\text { relations }\end{array}$ & & & 1,10 & & 1,10 & & 1,10 & & 1,10 & & 6,59 & 1,10 & $\begin{array}{l}10,9 \\
9\end{array}$ & 1,10 & 12,09 \\
\hline $\begin{array}{l}\text { Social } \\
\text { media } \\
\text { relations }\end{array}$ & 2,20 & & & & 2,20 & & 1,10 & & & $\begin{array}{l}1,1 \\
0\end{array}$ & 2,20 & $\begin{array}{l}10,9 \\
9\end{array}$ & 7,69 & 1,10 & 8,79 \\
\hline $\begin{array}{l}\text { Crisis } \\
\text { management }\end{array}$ & 2,20 & & 5,49 & & 2,20 & & 2,20 & & 2,20 & $\begin{array}{l}2,2 \\
0\end{array}$ & 6,59 & $\begin{array}{l}10,9 \\
9\end{array}$ & $\begin{array}{l}20,8 \\
8\end{array}$ & $\begin{array}{l}13,1 \\
9\end{array}$ & 34,07 \\
\hline $\begin{array}{l}\text { Internal } \\
\text { communicat } \\
\text { ion }\end{array}$ & 4,40 & & & & 2,20 & & & $\begin{array}{l}1,1 \\
0\end{array}$ & 2,20 & $\begin{array}{l}2,2 \\
0\end{array}$ & & 2,20 & 8,79 & 5,49 & 14,29 \\
\hline $\begin{array}{l}\text { Special } \\
\text { event, } \\
\text { conferencies }\end{array}$ & & & & & & & 1,10 & & & & 1,10 & & 2,20 & 0,00 & 2,20 \\
\hline $\begin{array}{l}\text { Stakeholder } \\
\text { relations }\end{array}$ & 1,10 & & 1,10 & $\begin{array}{l}1,1 \\
0\end{array}$ & 1,10 & & 1,10 & & & $\begin{array}{l}1,1 \\
0\end{array}$ & & & 4,40 & 2,20 & 6,59 \\
\hline & & & & & & & & & & & & & $\begin{array}{l}74,7 \\
3\end{array}$ & $\begin{array}{l}25,2 \\
7\end{array}$ & $\begin{array}{l}100,0 \\
0\end{array}$ \\
\hline
\end{tabular}

Source: compiled by authors

According to the study, professional PR associations offer these relevant activities to professionals. During the research period it was found that professional PR associations mostly focused on crisis communication (34\% of all competencies, $21 \%$ and $13 \%$ of competencies identified on the webpages of IPRA and GA, respectively, during the study period). It should be noted that crisis management and communication competencies are most often mentioned among all competencies suitable for employees at this level (see Figure 1).

Second, in terms of the importance and frequency of mention, competency is media relations. It accounts for $21 \%$ of all competencies and $21 \%$ and $13 \%$ of the competencies highlighted on the webpages of IPRA and GA, respectively, during the study period. The study highlighted that professional PR associations, when discussing media relations, indicate customary media relations separately ( $12 \%$ of all the mentioned competencies), and social media relations ( $9 \%$ of all competencies mentioned).

The third group of competencies stakeholder relations, which is distinguished by the frequency of mention and accounted for $18 \%$ of all mentions of competencies. While mentioning these competencies, professional PR associations indicate client management as an important area of competencies, accounting for about $11 \%$ of competencies mentioned by all PR associations during the research. 
Changes in communication management roles due to globalization: A case of communication management competencies mapped by international professional public relations associations (2015-2020)

Authors: Renata Matkevičienè, Lina Jakučionienè

Figure 1: Competencies in PR activities assigned to entry-level professionals, beginners or working in the field at the operational level (2015-2020, n-91, data in percentage)

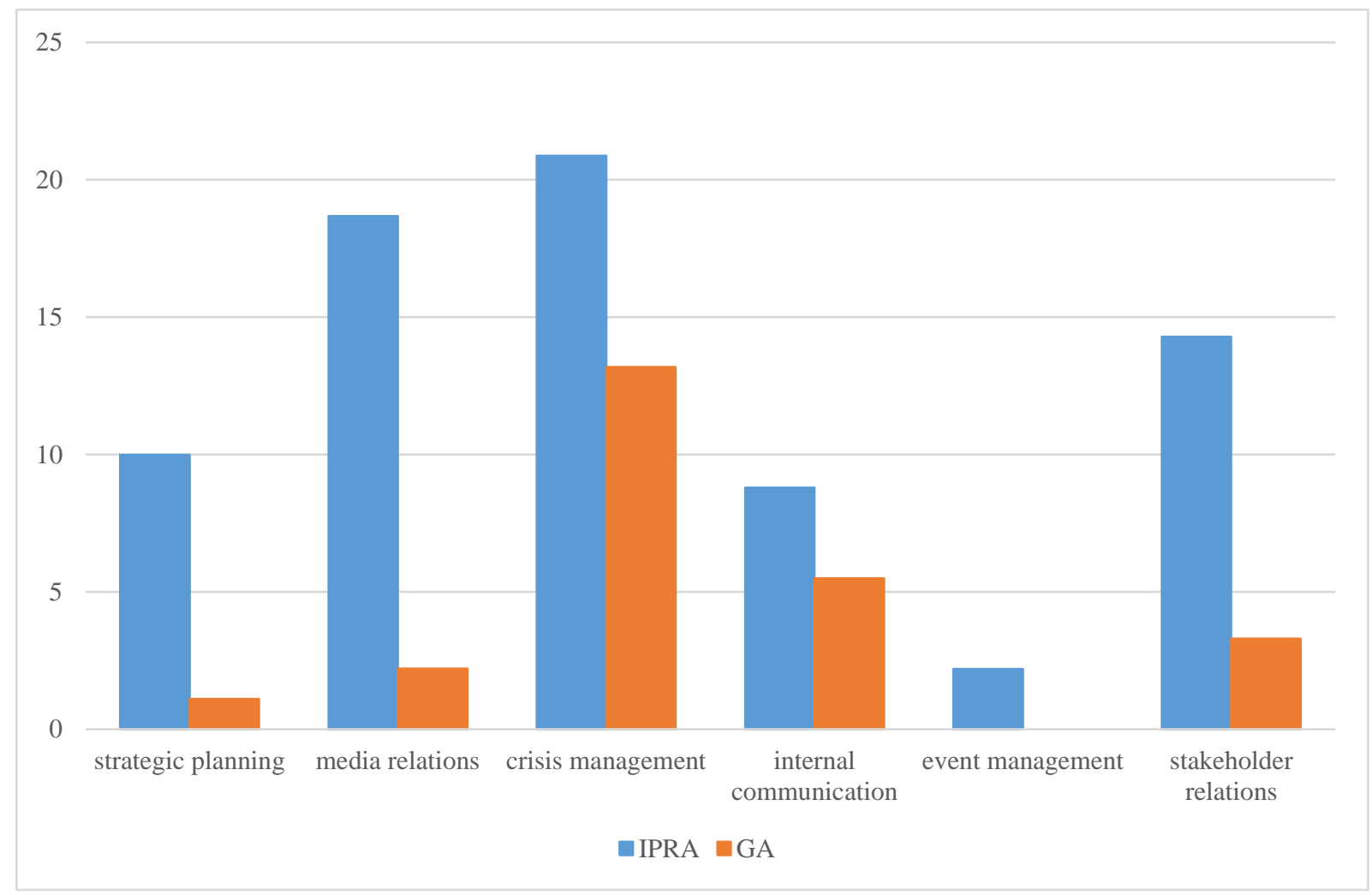

Source: compiled by authors

Knowledge and skills necessary for implementing internal communication activities are indicated as important competencies and account for approximately $14 \%$. Notably, both PR associations highlighted internal communication and crisis management competencies as important.

Analysis of the research data shows a significant focus of IPRA on providing competencies specific to beginners and entry-level PR specialists - almost $75 \%$ of all the above-mentioned competencies are related to activities and publications organised by IPRA, and only $25 \%$ of the competencies were mentioned in the information published by GA.

Competencies that are specific and attributable to senior and top-level PR specialists provided on the webpages of IPRA and GA were mentioned much more frequently than the competencies of beginners or specialists at the lower levels of management, accounting for almost $80 \%$ of all the above-mentioned competencies.

Competencies identified in the information provided by the surveyed organisations are divided into the following groups based on the frequency of their mention: reputation management, strategic management, digital platforms, and various stakeholder relationships (see Table 2). 
Table 2: Competencies assigned to senior and top-level PR specialists (2015-2020, n-337, data in percentage)

\begin{tabular}{|c|c|c|c|c|c|c|c|c|c|c|c|c|c|c|}
\hline & 2015 & & 2016 & & 2017 & & 2018 & & 2019 & & 2020 & & $\begin{array}{l}\text { Tota } \\
\text { l }\end{array}$ & \\
\hline $\begin{array}{l}\text { Competencie } \\
\text { s/ activities }\end{array}$ & $\begin{array}{l}\text { IPR } \\
\text { A }\end{array}$ & GA & $\begin{array}{l}\text { IPR } \\
\text { A }\end{array}$ & GA & $\begin{array}{l}\text { IPR } \\
\text { A }\end{array}$ & GA & $\begin{array}{l}\text { IPR } \\
\text { A }\end{array}$ & GA & $\begin{array}{l}\text { IPR } \\
\text { A }\end{array}$ & GA & $\begin{array}{l}\text { IPR } \\
\text { A }\end{array}$ & GA & $\begin{array}{l}\text { IPR } \\
\text { A }\end{array}$ & GA \\
\hline $\begin{array}{l}\text { Reputation } \\
\text { management }\end{array}$ & 1,48 & & 0,89 & & 0,89 & & 0,89 & & 1,78 & $\begin{array}{l}0,5 \\
9\end{array}$ & 2,97 & 0,89 & 8,90 & 1,48 \\
\hline $\begin{array}{l}\text { Building and } \\
\text { maintaining } \\
\text { trust and } \\
\text { relationship } \\
\text { with the } \\
\text { stakeholders } \\
\text { and } \\
\text { communities }\end{array}$ & 1,19 & & 0,89 & & 1,78 & $\begin{array}{l}0,3 \\
0\end{array}$ & 1,19 & $\begin{array}{l}0,8 \\
9\end{array}$ & 0,30 & $\begin{array}{l}1,1 \\
9\end{array}$ & 0,30 & $\begin{array}{l}21,0 \\
7\end{array}$ & 5,64 & $\begin{array}{l}23,4 \\
4\end{array}$ \\
\hline $\begin{array}{l}\text { Government } \\
\text { relations and } \\
\text { public affairs }\end{array}$ & 0,30 & & 0,30 & & 0,30 & & 0,30 & & 0,30 & & & & 1,48 & 0,00 \\
\hline $\begin{array}{l}\text { Digital } \\
\text { literacy/ } \\
\text { digital } \\
\text { platforms }\end{array}$ & 0,30 & & 0,89 & & 1,78 & $\begin{array}{l}0,3 \\
0\end{array}$ & 1,19 & & 0,89 & $\begin{array}{l}3,8 \\
6\end{array}$ & 1,19 & 3,26 & 6,23 & 7,42 \\
\hline $\begin{array}{l}\text { Strategic } \\
\text { management }\end{array}$ & 1,19 & $\begin{array}{l}0,8 \\
9\end{array}$ & 0,59 & $\begin{array}{l}1,7 \\
8\end{array}$ & 0,59 & $\begin{array}{l}1,1 \\
9\end{array}$ & 1,78 & $\begin{array}{l}0,3 \\
0\end{array}$ & 2,08 & $\begin{array}{l}2,9 \\
7\end{array}$ & 2,67 & 3,86 & 8,90 & $\begin{array}{l}10,9 \\
8\end{array}$ \\
\hline $\begin{array}{l}\text { Continuing } \\
\text { professional } \\
\text { learning }\end{array}$ & & $\begin{array}{l}0,5 \\
9\end{array}$ & 0,30 & $\begin{array}{l}0,3 \\
0\end{array}$ & & $\begin{array}{l}0,5 \\
9\end{array}$ & & $\begin{array}{l}0,3 \\
0\end{array}$ & 0,30 & $\begin{array}{l}2,9 \\
7\end{array}$ & & $\begin{array}{l}20,1 \\
8\end{array}$ & 0,59 & $\begin{array}{l}24,9 \\
3\end{array}$ \\
\hline
\end{tabular}

Source: compiled by authors

Analysis of reports of professional PR associations highlighting competencies relevant to senior and top-level PR specialists differs from the general competencies emphasised in the activities of professional PR associations for novice PR specialists; more attention is paid to strategic communication, stakeholder relationships, and community; however, competencies such as reputation management, trust management, digital literacy, and professional training, which are not emphasised for beginners in the field, are presented as important for senior and top-level professionals.

Among professional PR associations, prominent competencies mentioned for senior and toplevel PR professionals are stakeholder relationships (30\% of competencies that are mentioned as important for professionals: at $6 \%$ for IPRA and $24 \%$ for GA) (see Figure 2). This group of competencies includes skills relevant to professionals, which help to build relationships with various stakeholders in organisations while performing activities such as government relations and public affairs, stakeholder and community relations, trust building, and value proposition for stakeholders. 
Changes in communication management roles due to globalization: A case of communication management competencies mapped by international professional public relations

associations (2015-2020)

Authors: Renata Matkevičiené, Lina Jakučionienè

Figure 2: Competencies assigned to senior and top-level PR specialists (2015-2020, n-337, data in percentage)

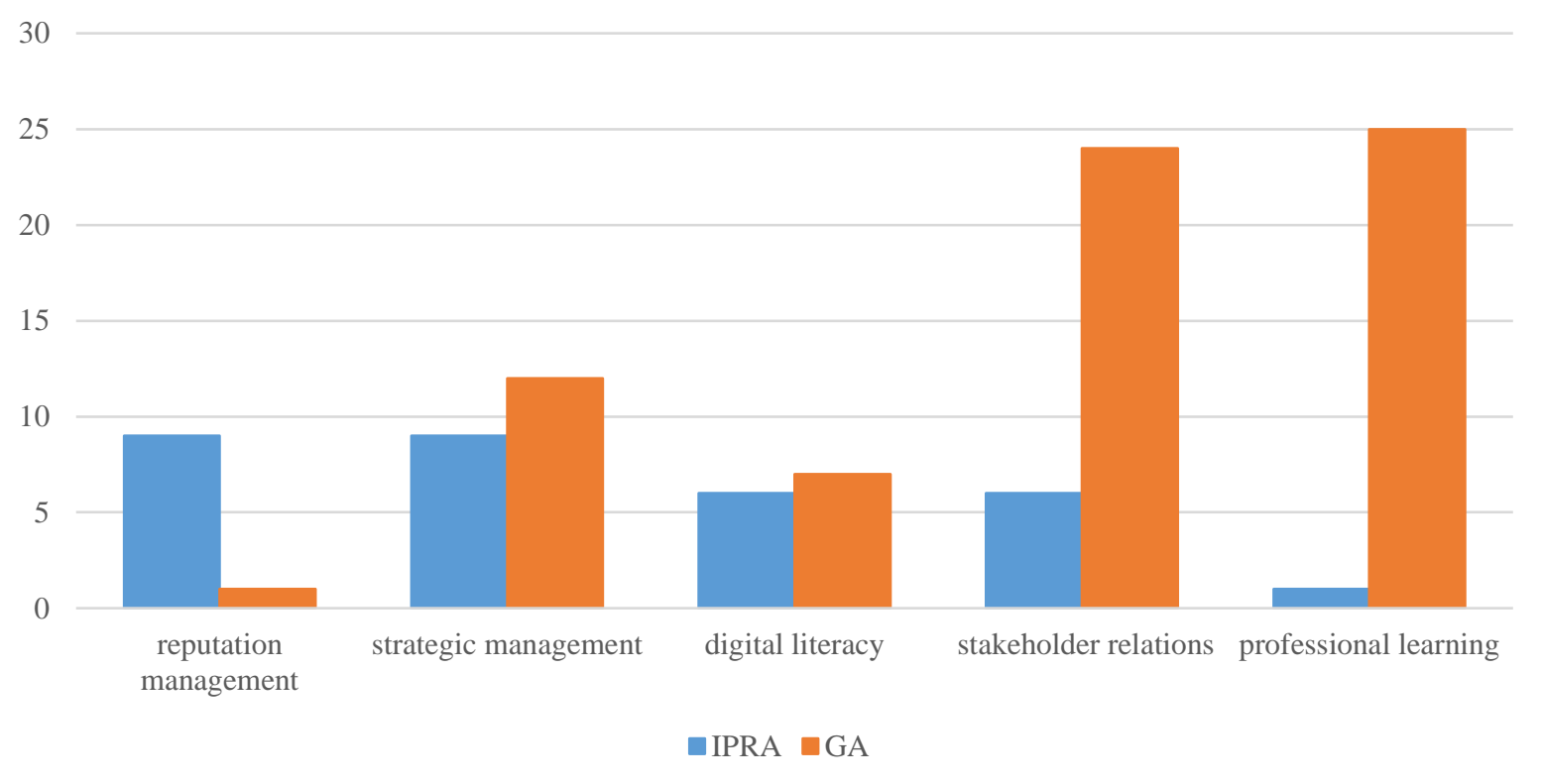

Source: compiled by authors

One of the most important competencies relevant to senior and top-level PR specialists is strategic management and communication, accounting for about $21 \%$ of all the competencies relevant to professionals at this level. This group of competencies includes competencies such as evaluation and measurement, evaluation research, advanced environmental scanning and trend identification, and issue identification. These competencies are consistently highlighted during the study period, but their emphasis has intensified in recent years.

Organizational reputation management competencies (10\%), including organizational leadership and ethical competencies, are emphasised for senior and top-level PR specialists. The research data show that reputation management competencies are consistently mentioned in the reports of the surveyed organisations during the study period. A significant increase in the focus on this topic is observed in 2020, and this can be attributed to professional PR associations' exclusive focus on ethical issues while expressing leadership assumed by professional PR associations in this field.

Another uniqueness is digital literacy or managing digital platforms, which account for about $13 \%$ of all competencies that have been consistently updated, but their relevance is becoming sharper, especially from 2018 onwards. The equal focus of professional PR associations on digital literacy and work with digital platforms is also consistent with the need for and response to beginner and operational levels of PR professionals in providing social media skills.

Uniqueness that is not typical for beginners or operational level PR specialists is professional learning, which accounts for about $26 \%$ of PR professionals at this level, as highlighted by all PR associations. Professional learning competencies are evenly distributed during the study period, but it is also noticeable that the professional learning competencies of PR specialists at this level are more prominent in the GA professional PR association reports. This is also confirmed by the significant increase in the number of relevant reports in 2020 , which highlight continuous professional learning competence to which GA paid special attention in 2020.

Activities that provide PR competencies, as indicated in the reports of professional PR associations, correspond to the general prevailing competence development activities such as publications in the professional field, trainings, and conferences (see Table 3). 
Table 3: Activities of professional PR associations for the development of competencies of PR specialists (20152020, n-428, data in percentage)

\begin{tabular}{|c|c|c|c|c|c|c|c|c|c|c|c|c|c|}
\hline \multirow[b]{2}{*}{$\begin{array}{l}\text { Information } \\
\text { activities }\end{array}$} & \multicolumn{2}{|l|}{2015} & \multicolumn{2}{|l|}{2016} & \multicolumn{2}{|l|}{2017} & \multicolumn{2}{|l|}{2018} & \multicolumn{2}{|l|}{2019} & \multicolumn{2}{|l|}{2020} & $\begin{array}{l}\text { Tota } \\
1\end{array}$ \\
\hline & $\begin{array}{l}\text { IPR } \\
\text { A }\end{array}$ & GA & $\begin{array}{l}\text { IPR } \\
\text { A }\end{array}$ & GA & $\begin{array}{l}\text { IPR } \\
\text { A }\end{array}$ & GA & $\begin{array}{l}\text { IPR } \\
\text { A }\end{array}$ & GA & $\begin{array}{l}\text { IPR } \\
\text { A }\end{array}$ & GA & $\begin{array}{l}\text { IPR } \\
\text { A }\end{array}$ & GA & \\
\hline Articles & 6,31 & & 4,91 & & 5,61 & $\begin{array}{l}0,9 \\
3\end{array}$ & 4,67 & $\begin{array}{l}0,7 \\
0\end{array}$ & 4,44 & $\begin{array}{l}1,1 \\
7\end{array}$ & 4,67 & $\begin{array}{l}18,4 \\
6\end{array}$ & $\begin{array}{l}51,8 \\
7\end{array}$ \\
\hline $\begin{array}{l}\text { Information } \\
\text { about activities } \\
\text { of associations }\end{array}$ & 0,00 & $\begin{array}{l}1,1 \\
7\end{array}$ & 0,70 & $\begin{array}{l}1,8 \\
7\end{array}$ & 1,17 & $\begin{array}{l}0,9 \\
3\end{array}$ & 1,40 & $\begin{array}{l}0,7 \\
0\end{array}$ & 2,10 & $\begin{array}{l}9,5 \\
8\end{array}$ & 4,91 & $\begin{array}{l}23,6 \\
0\end{array}$ & $\begin{array}{l}48,1 \\
3\end{array}$ \\
\hline Among those: & & & & & & & & & & & & & \\
\hline $\begin{array}{l}\text { Conferences, } \\
\text { trainings }\end{array}$ & 0,00 & $\begin{array}{l}0,7 \\
0\end{array}$ & 0,70 & $\begin{array}{l}1,6 \\
4\end{array}$ & 1,17 & $\begin{array}{l}0,7 \\
0\end{array}$ & 1,17 & $\begin{array}{l}0,2 \\
3\end{array}$ & 2,10 & $\begin{array}{l}9,8 \\
1\end{array}$ & 4,91 & $\begin{array}{l}21,9 \\
6\end{array}$ & $\begin{array}{l}45,0 \\
9\end{array}$ \\
\hline $\begin{array}{l}\text { Reports on PR } \\
\text { profession/ } \\
\text { recommendatio } \\
\text { ns }\end{array}$ & 0,00 & $\begin{array}{l}0,4 \\
7\end{array}$ & 0,00 & $\begin{array}{l}0,2 \\
3\end{array}$ & 0,00 & $\begin{array}{l}0,2 \\
3\end{array}$ & 0,23 & $\begin{array}{l}0,4 \\
7\end{array}$ & 0,00 & $\begin{array}{l}1,4 \\
0\end{array}$ & 0,00 & 1,17 & 4,21 \\
\hline
\end{tabular}

Source: compiled by authors

The research data show that professional PR associations communicate about PR competencies by publishing articles prepared by association members, association reports, or by sharing professional and mainstream media prepared or published by partners (i.e. other communication agents or higher education institutions); about $52 \%$ of all activities that present relevant PR competencies consist of articles that professional PR associations share with the community on the associations' webpages. In assessing the distribution of messages, it can be noticed that the distribution of messages about the competencies of PR specialists is almost even on the webpages of both professional PR associations examined in this study (IPRA: $31 \%$ and GA: $21 \%$ of all PR communication activities devoted to communication competencies).

While analysing the research data, it is observed that professional PR associations conduct various activities to provide PR specialists with the necessary competencies, and the number of reports on those activities makes up about $48 \%$ of all publications related to competencies published on the webpages of professional PR associations. While analysing the distribution of activities, it can be viewed that GA provides more information on various activities in the communication where the presentation of these activities is $38 \%$ of all communications, and these messages account for about $10 \%$ of all messages. The research data also show that to provide competencies, professional PR associations not only organise various events, conferences, and seminars (this data accounts for $18 \%$ of all information related to competencies) but also seek help from their partners - $17 \%$ of training reports in the communication of the surveyed professional PR associations - information about training, seminars, or conferences conducted by partners, in which members of professional PR associations are also invited to participate. Analysis of the communication revealed an equal distribution of information about training and seminars: about $12 \%$ of the trainings were organised by professional PR associations and slightly more than $12 \%$ were organised by partners. A marginally different distribution pattern is noticed when analysing information about trainings-information about trainings organised by professional PR associations accounts for about $1 \%$ of the total information flow related to competencies, while information about trainings organised by partners accounts for over $15 \%$ of all communication. Notably, information about study programs related to the field and offered by higher education 
Changes in communication management roles due to globalization: A case of communication management competencies mapped by international professional public relations

associations (2015-2020)

Authors: Renata Matkevičienè, Lina Jakučionienè

institutions in the total communication flow account for about $2 \%$. However, the study found a trend that professional PR associations actively share information about higher education institutions' internships and other cooperation opportunities; in terms of the relationship of this information to the total flow of information related to the competencies of PR specialists, it accounts for about half of the total communication (for this reason, these messages were not included in the overall flow of the analysed communication).

One of the activities that is singled out as important and provides PR specialists knowledge about the market situation is dissemination of information about PR research, accounting for about $4 \%$ of all communication in the total communication flow.

While analysing the distribution of competencies not only by individual professional PR associations but also by year, it can be observed that some competencies are highlighted during separate periods.

The time gap between the competencies and actions of the respective professional PR associations, which correspond to the expressed competence, was determined by performing a qualitative analysis of the communication content of the researched organisations webpages.

The analysis shows that the gap between the identification of required competencies and the respective activities provided by professional PR associations depends on their relevance to traditional competencies. The analysis shows that a large number of activities is focused on the development of traditional competencies rather than the development of such competencies, for which the greatest need is expressed.

For comparison, during the research period between 2015-2020, 70 activities were dedicated to the development of TOP 5 competencies: training, $11 \%$; conferences, $42 \%$; seminars, $6 \%$; articles, 38\%; and others, 3\%. Nearly 88 activities are aimed at improving traditional competencies, the excess of which is distinguished by PR specialists: training, 20\%; conferences, $32 \%$; seminars, $8 \%$; articles, $34 \%$; and others, $6 \%$.

The study shows that one of the factors that affects the time gap is the order of activities that provide the relevant competencies: first, sharing of good practices and scientific-theoretical activities (educational articles, scholarly insights, conference presentations) are offered, and in a few years, appropriate training is provided. Trainings, where PR specialists can develop the required competencies in practice, are offered latest (see Fig. 3).

While analysing the time interval from the moment the need for competencies is identified, we observe that the need for competence development in practice (trainings) responds in about four years. For example, the need for competence that links business and communication strategies is expressed constantly (i.e. it was among the top one or two in 2015-2018), while training for PR specialists is offered in 2020, although the need in 2020 is only in seventh position. The need for competence coping with digital evolution and social web is also constantly expressed (in 2015-2018 this competence is among the top 2, top 3, top 31, respectively), while there was practical response for the need to improve competence in 20192020 , when the need is only at 5th and 8th position in the order of importance. 
Figure 3: Trainings organized of professional PR associations for the development of competencies of PR specialists (2015-2020, n-428)
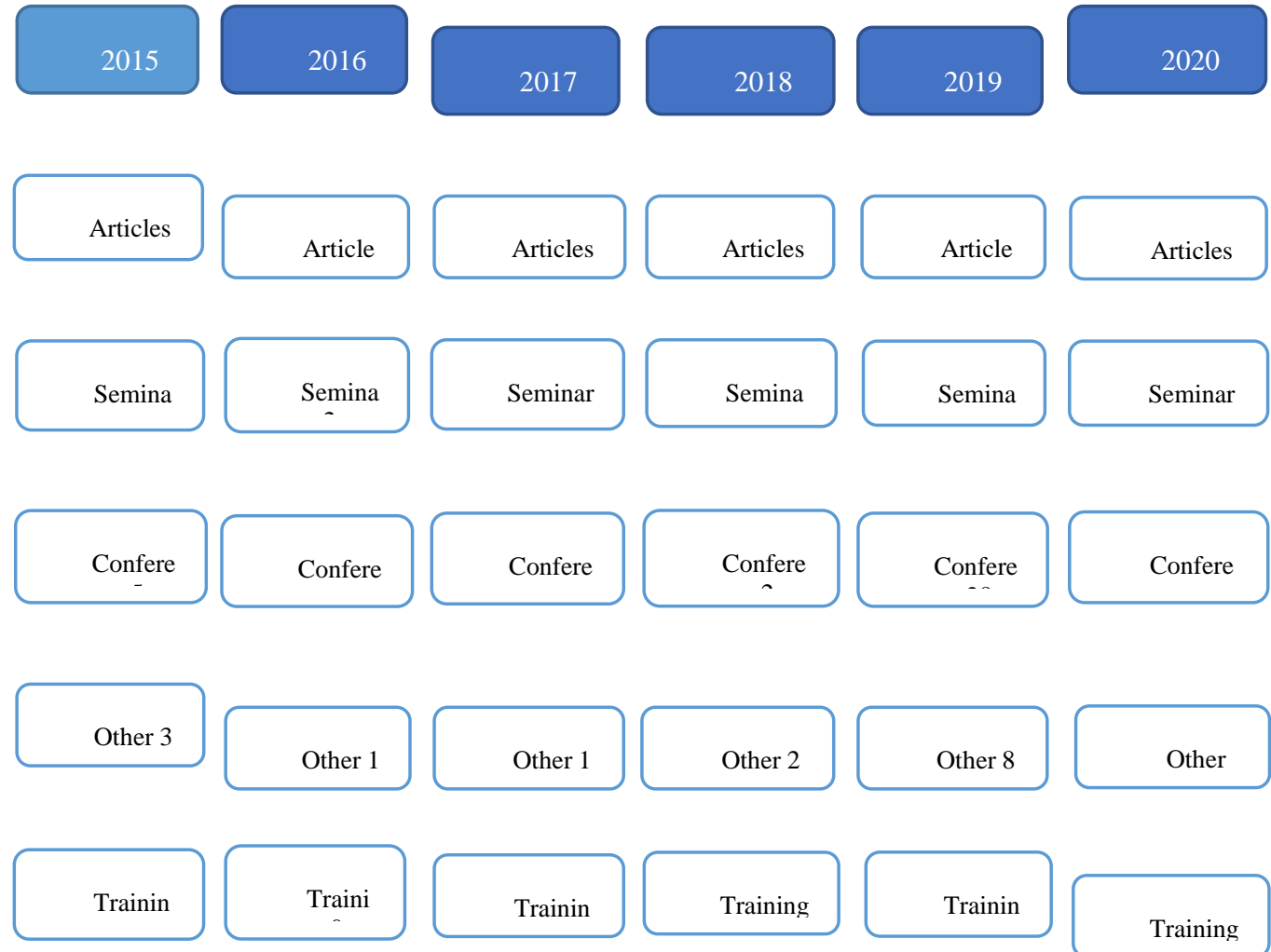

Training

Source: compiled by authors

\section{Discussion}

As evident, the changing environment is shaping the need for new competencies for PR professionals; however, they are only offered training to improve traditional competencies such as crisis management, reputation management, media relations, communication skills, technical professional skills (how to prepare a media report, prepare for radio or television interviews), although PR professionals emphasise that such trainings are already in excess (Tench et al., 2013; Zerfass et al., 2018; MacNamara et al., 2017; USC Annenberg Centre for Public Relations, 2017). The survey data support the view that PR professional associations focus on typical PR competencies, such as media relations, crisis management, and reputation management (see Tables 1 and 2). In response to the competencies identified by employers and highlighted by PR professionals as important and often necessary, PR associations recently (especially at the beginning of 2018) paid more attention to communication, thus reflecting the activities of PR professional associations such as building and maintaining trust, which is an ethical framework of the PR profession (see Figure 3).

The need raised by employers for the strategic and technological competencies of PR specialists also corresponds to the need expressed by PR specialists themselves. Research emphasises that communication must form a part of an organization's strategic management (Thøger Christenssen et al., 2013; Grunig, 2006), but linking communication to business strategy remains a major challenge worldwide for communication professionals' strategic management (including not only operational competencies but also environmental scanning, 
Changes in communication management roles due to globalization: A case of communication management competencies mapped by international professional public relations

associations (2015-2020)

Authors: Renata Matkevičiené, Lina Jakučionienè

evaluation of communication activities, and performance measurement) and reputation management (see Tables 1 and 2).

Employers' criterion for PR specialists' having competence in strategic and technological management is determined by fierce competition in the context of a changing environment. This correlates with the general labour market trends emphasising the importance of technological, social, and cognitive skills, including analytics, business priority knowledge, and leadership in the context of environmental transformation (MacCrory et al., 2014; Skill Needs, 2018; Smith, 2017). According to available research data, although the speed and volume of information flow together with big data and application of algorithms for communication was already raised by specialists as an important competence in 2015, information and relevant activities providing and enabling the development of these competencies are limited, and they are distributed based on the conventional approach to PR activities, that is, based on the respective areas of activity of PR specialists such as media relations, social media relations, digital platforms, environmental scanning and measurement, and evaluation (see Figures 1 and 2; Tables 1 and 2). However, according to the current issues, PR specialists need integrated, comprehensive information flow, big data, and digital platforms for the application of competencies for PR activities (see Fig. 4).

Figure 4: TOP competencies are identified, which, depending on the respective year, get to the TOP 5 (based on ECM (2015-2020)

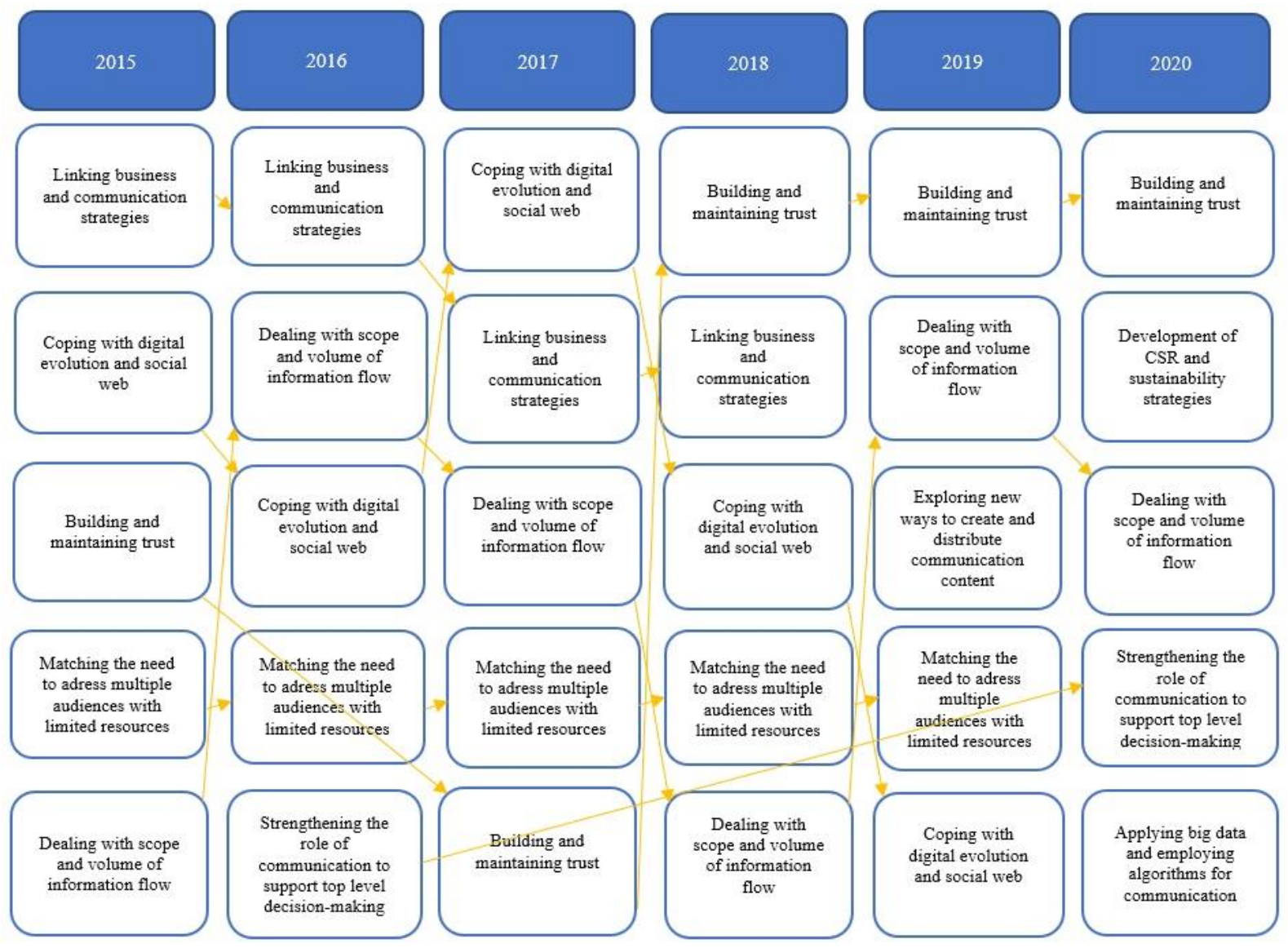

Source: compiled by authors

The impact of digital transformation is seen as the need for PR professionals to identify new competencies that demand information technology (IT) skills. This study has identified changes in competencies that were perceived as relevant and necessary during the study period, driven 
by digital transformation trends. This research has identified a time gap between the expressed need or trend, showing the relevance of a certain competence, and the opportunities to acquire, form, and strengthen the relevant competencies in time, using competence formation and development offered by professional associations. The study results show that professional PR associations do not respond in a timely manner to the challenges of the changing environment through training, but present and discuss relevant topics with the help of specialists from other fields, while encouraging sharing of good practices. This functional position of professional PR associations in the model of competence development of PR specialists shows that PR associations are involved in strengthening and maintaining competencies rather than creating them.

\section{Conclusion}

The impact of digital transformation on the professional field is being discussed among PR specialists, but professional PR associations are more focused on digital activities such as digital platforms and digital literacy. An analysis of communication between professional PR associations shows a clear distinction between activities for various levels of PR professionals that distinguishes between communication and activities that provide certain knowledge and skills, case presentations or advice for entry-level specialists, and senior and top-level PR professionals.

Public relations associations tend to focus more on the selected circle of PR professionals. The research data also show that a tendency for fragmentation and segregation of competencies persists, although the challenges of digital transformation for competence change are obvious. When professional PR associations communicate the competencies of PR specialists, they highlight the specifics of individual activities, but do not provide an integrated, broader approach to competencies. This trend is evident in communication messages, which are aimed at beginners or PR specialists engaged at the operational level.

There is a time gap between the competencies expressed by PR specialists as important and lacking, and the activities provided by professional PR associations. Primarily, exchange of good practices, scientific and theoretical activities are offered, and appropriate training is provided after a few years.

The gap between demand and supply correlates with the results of previous studies. While they signal the need for constant improvement of competencies, especially business development and technology, professional PR associations focus more on the development of customary competencies than on competencies that PR specialists demand and deem as important in the changing environment.

Research findings that presume the existing gap highlight the need for further empirical research because studies explaining the global map of PR competencies and its correlation with activities to ensure life-long learning opportunities for PR professionals are limited.

The activities of professional PR associations identified during the research in the development of competencies of PR specialists reveal that PR associations are engaged in strengthening and maintaining competencies rather than building them.

However, as mentioned earlier, the responsibility for developing competencies in the PR profession is divided among three participants: professional PR associations, organisations (employers), and PR specialists themselves, who must invest in their professional development.

\section{Study limitations}

References to the competencies explored, based on information provided on the Internet, may lead to inaccurate data as the activities of PR associations and active communication with 
Changes in communication management roles due to globalization: A case of communication management competencies mapped by international professional public relations associations (2015-2020)

Authors: Renata Matkevičienè, Lina Jakučioniené

members of associations through various forms of internal communication - newsletters, social media platforms, direct letters - were not examined in the research. The chosen research scale may impact data and lead to different trends in the study, both in terms of designation of the competence by PR associations and the time scale of their realisation.

The limitations may also be due to the application of selected research methods. The texts by PR associations were coded by applying essential keywords describing specific competencies, and this may also be impacted by the fact that competencies were identified in messages using different terms.

\section{References}

Adi, A. (2019). PR2025: trends, competences and solutions for the near future of PR/Communications - Results of a Delphi method study. Quadriga University of Applied Sciences. Retrieved from: Avaliable at: https://www.quadriga-hochschule.com/app/uploads/2021/03/QHS_PR2025_Adi.pdf.

Agency for Strategic Initiatives. Annual Report (2015). Available at: https://kokos-asi-productionice.asi.ru/iblock/106/106dc8949162756da098a54d18484fb1/ASI_Annual_Report_2015.pdf.

Amankwah-Amoah, J., Khan, Z., \& Woodc, G. (2020). COVID-19 and business failures: The paradoxes of experience, scale, and scope for theory and practice. European Management Journal.

Ateş, Y. N., Tarakci, M., Porck, P., J., Daan van Knippenberg, \& Groenen, J.F. (2018). The dark side of visionary leadership in strategy implementation: Strategic alignment, strategic consensus, and commitment. Journal of Management, 46(5), 637-665.

Brambilla, I., \& Tortarolo, D. (2018). Investment in ICT, productivity, and labor demand: The case of argentina. Documento de Trabajo Nro. 116, Junio 2018. Departamento deEconomíae Instituto de Investigaciones Económicas. Available at: http://sedici.unlp.edu.ar/bitstream/handle/10915/67688/Documento_completo.pdfPDFA.pdf?sequence $=1$.

Buchel, F. (2002). The effects of overeducation on productivity in Germany - the firms' viewpoint. Economics of Education Review, 21, 263-275.

Ciolacu, M., Svasta, P., Berg, W., \& Popp, H. (2017). Education 4.0 for tall thin engineer in a data driven society. 2017 IEEE 23rd International Symposium for Design and Technology in Electronic Packaging (SIITME), 432437.

Communicating AI: Building the Playbook for Communication Professionals (2019). Centre for Strategic Communication Excellence. Retrieved from: https://www.cropleycomms.com/hubfs/5174693/Communicating_AI_Building_the_Playbook_2019.pdf.

De la Fuente, A., \& Ciccone, A. (2003). Human capital in a global and knowledge-based economy. Education + Training, 45(8/9). Available at: https://www.emerald.com/insight/publication/issn/0040-0912.

Delamare Le Deist, F., \& Winterton, J. (2005). What is competence? Human Resource Development International, $8(1), 27-46$.

Deming, D. J. (2017). The value of soft skills in the labor market. The Reporter, 4. Available at: https://www.nber.org/reporter/2017number4/value-soft-skills-labor-market.

Dozier, D. M., \& Broom, G, M. (1995). Evolution of the manager role in public relations practice. Journal of Public Relations Research, 7(1), 3-26.

during Non-work Time: A narrative synthesis of empirical research and research agenda. International Journal of Management Reviews, 20, 825-846.

Fawkes, J., Gregory, A., Falkheimer, J., Gutiérrez-García, E., Halff, G., Rensburg, R., Sadi, G., Sevigny, A., Sison, M.D., Thurlow, A., Tsetsura, K., \& Wolf, K. (2018). A Global Capability Framework for the public relations and communication management profession. Global alliance for public relations and communication management (GA) research report. Huddersfield, UK: University of Huddersfield. Available at: https://prinz.org.nz/wp-content/uploads/2020/09/Global_Capability_Framework.pdf.

Feldman, B. (2017). Changing skills for a changing landscape. The relevance report. 2017. USC Annenberg Centre for Public Relations: Los Angeles, CA, 26-27. Available at: https://annenberg.usc.edu/research/centerpublic-relations/relevance-report. 
From the global body of knowledge to a global capabilities framework. Global Alliance (2016). Global Alliance, May 2016. Available at: https://static1.squarespace.com/static/561d0274e4b0601b7c814ca9/t/574ae46707eaa010521f0d31/14645259 36413/08_GBOK+Progress+report+\%26+global+capabilities+framework+May+2016.pdf.

Getting skills right: Assessing and anticipating changing skill needs. The Organisation for Economic Co-operation and Development/ OECD (2016). OECD Publishing, Paris.

Goos, M., Manning, A., \& Salomons, A. (2014). Explaining job polarization: Routine-biased technological change and offshoring. The American Economic Review, 104(8), 2509-2526.

Grunig, J. E. (2006). Furnishing the edifice: Ongoing research on public relations as a strategic management function. Journal of Public Relations Research, 18(2), 151-176.

Grunig, J. E., \& Hunt, T. (1984). Managing public relations. New York, NY: Holt, Rinehart and Winston.

Grunig, J. E., \& Repper, F. C. (1992). Strategic management, publics, and issues. Excellence in Public Relations and Communication Management / James E. Grunig (Ed.). Hillsdale, NJ: Lawrence Erlbaum Associates, 117158.

Hager, P. (2004). The competence affair, or why vocational education and training urgently needs a new understanding of learning. Journal of Vocational Education \& Training, 56(3), 409-433.

Hartog, J. (1992). Capabilities, allocation and earnings. Boston: Kluwer, 324.

Hegyes, E., G., Csapó, I., \& Farkas, F. M. (2017). Some aspects of digitalization and sustainability in the European Union. Journal of Management, 2(31).

Hunt, G. J. F. (1997). Instruction and evaluation: Design principles in instructional design. In Hunt, G.J.F. (Ed.), Designing Instruction for Human Factors Training in Aviation, Avebury Aviation, Aldershot, 312.

Insights into skill shortages and skill mismatch: Learning from Cedefop's European skills and jobs survey (2018). Cedefop, Cedefop reference series; No 106. Luxembourg: Publications Office. Available at: http://data.europa.eu/doi/10.2801/645011.

Jeffrey, L. M, \& Brunton, M. A. (2011). Developing a framework for communication management competencies. Journal of Vocational Education and Training, 63(1), 57-75.

Khosravi, P., Newton, C., \& Rezvani, A. (2019). Management innovation: A systematic review and meta-analysis of past decades of research. European Management Journal.

Kumar, N., Scheer, L., \& Kotler, P. (2000). From market driven to market driving. European Management Journal, $18(2), 129-142$.

Lee, H., W., Pak, J., Kim, S., \& Li, L.-Z. (2016). Effects of human resource management systems on employee proactivity and group innovation. Journal of Management, 45(2).

Liedtka, J. (2000). Strategic planning as a contributor to strategic change: A generative model. European Management Journal, 18(2), 195-206.

Lokshin, B., van Gils, A. E. J., \& Bauer, E. (2009). Crafting firm competencies to improve innovative performance. European Management Journal, 27(3), 187-196.

MacCrory, F., Westerman, G., AlHammadi, Y., \& Brynjolfsson, E. (2014). Racing With and Against the Machine: Changes in Occupational Skill Composition in an Era of Rapid Technological Advance. In ICIS. Proceedings of the Thirty Fifth International Conference on Information Systems: Building a Better World through Information Systems, Auckland, New Zealand, December 2014; AIS/ICIS Administrative Office: Atlanta, Georgia. Available at: https://www.semanticscholar.org/paper/Racing-With-and-Against-the-Machine\%3AChanges-in-in-MacCrory-Westerman/aa2ee78a1a63951f53341c0e63b6d470e3e77388.

Macnamara, J. (2018a). A review of new evaluation models for strategic communication: Progress and gaps. International Journal of Strategic Communication, 12(2), 180-195.

Macnamara, J. (2018b). Competence, competencies and/or capabilities for public communication? A public sector study. Asia Pacific Public Relations Journal, 19, 16-40.

Macnamara, J., Lwin, M. O., Adi, A., \& Zerfass, A. (2015). Asia-Pacific communication monitor 2015/16. The state of strategic communication and public relations in a region of rapid growth. Survey results from 23 countries, APACD, Hong Kong.

Macnamara, J., Lwin, M. O., Adi, A., \& Zerfass, A. (2017). Asia-Pacific communication monitor $2017 / 18$. Strategic challenges, social media and professional capabilities - Results of a survey in 22 countries. Hong 
Changes in communication management roles due to globalization:

A case of communication management competencies mapped by international professional public relations

associations (2015-2020)

Authors: Renata Matkevičienè, Lina Jakučioniené

Kong: APACD. Available at: https://www.communication-director.com/facts-figures/asia-pacificcommunication-monitor-2017/\#.YI-wlutgFpQ.

Manyika, J., Lund, S., Chui, M., Bughin, J., Woetzel, J., Batra, P., Ko, R., \& Sanghvi, S. (2017). Jobs lost, jobs gained: What the future of work will mean for jobs, skills, and wages. McKinsey Global Institute, November, 2017. Report. Available at: https://www.mckinsey.com/featured-insights/future-of-work/jobs-lost-jobsgained-what-the-future-of-work-will-mean-for-jobs-skills-and-wages.

Mulder, M. (2014). Conceptions of professional competence. International Handbook of Research in Professional and Practice-based Learning. Billett, S., Harteis, C., Gruber, H. (Eds.). Springer: (Springer International Handbooks of Education), 1383.

Piva, M, Enrico, S., \& Marco, V. (2006). Technological and organizational changes as determinants of the skill bias: Evidence from the Italian machinery industry. Managerial and Decision Economics, 27(1), 63-73.

Piva, M., Santarelli, E., \& Vivarelli, M. (2005). The skill bias effect of technological and organisational change: Evidence and policy implications. Research Policy,34(2), 141-157.

Prandi, M., Martell, J., \& Lozano, J.M. (2017). Learning in a social context. Available at: http://www.unprme.org/ resource-docs/LearninginaSocialContextReport.pdf.

Rajnai, Z., \& Kocsis, I. (2017). Labour market risks of industry 4.0, digitization, robots and AI. 2017 IEEE 15th International Symposium on Intelligent Systems and Informatics (SISY), Proceedings, 000343-000346.

Realizing human potential in the fourth industrial revolution. An agenda for leaders to shape the future of education, gender and work. (2017). World Economic Forum, White Pape, January, 2017. Available at: http://www3.weforum.org/docs/WEF_EGW_Whitepaper.pdf.

Re-imagining work. Work 4.0. (2017). White paper. Federal ministry of labour and social affairs. Available at: https://www.bmas.de/SharedDocs/Downloads/EN/PDF-Publikationen/a883-whitepaper.pdf?_blob=publicationFile\&v=3.

Schlachter, S., McDowall, A., Cropley, M., \& and Inceoglu, I. (2018). Voluntary Work-related Technology Use.

Sianesi, B., \& Reenen, J. V. (2003). The returns to education: Macroeconomics. Journal of Economic Surveys, $17(2), 157-200$.

Skill Needs (2018). The organisation for economic co-operation and development/OECD, 2018. Available at: https://stats.oecd.org/Index.aspx?DataSetCode=SKILLS_2018_TOTAL.

Smith, C. (2017). Skill demands and the developments in the advanced economies. The Oxford Handbook of Skills and Training/Warhurst, C., Mayhew, K., Buchanan, J. (Eds.). Oxford University Press: Oxford, UK.

Täuscher, K., \& Laudien, S. (2018). Understanding platform business models: A mixed methods study of marketplaces. European Management Journal, 36(3), 319-329.

Tench, R., Zerfass, A., Verhoeven, P., Verčič, D., Moreno, A., \& Okay, A. (2013). Competencies and role requirements of communication professionals in Europe. Insights from quantitative and qualitative studies. ECOPSI Research Project, 2013. Leeds Metropolitan University, Leeds, UK. Available at: http://eprints.leedsbeckett.ac.uk/id/eprint/818/.

The CEO communications audit prepared for the luc beauregard centre of excellence in communications research June (2017). Concordia.Ca/Jmsb. Available at: https://www.concordia.ca/content/dam/jmsb/docs/researchcentres/luc-beauregard/CEO-Summit-report.pdf.

The future of jobs. Employment, skills and workforce strategy for the fourth industrial revolution. Growth Strategies. (2016). Global Challenge Insight Report, January, 2016. World Economic Forum. Available at: http://www3.weforum.org/docs/WEF_Future_of_Jobs.pdf.

The future of jobs: Employment, skills and workforce strategy for the fourth industrial revolution. (2018). Centre for the New Economy and Society. Available at: http://www3.weforum.org/docs/WEF_Future_of_Jobs_2018.pdf.

Thøger, Ch. L., \& Cornelissen, J. (2011). Bridging corporate and organizational communication: Review, development and a look to the future. Management Communication Quarterly, 25(3), 383-414.

Uslu, Ö. (2017). Evaluating the professional development program aimed technology integration at the era of curriculum change. Educational Sciences: Theory \& Practice, 17(6), 2031-2055.

Vaseyskaya, N. O., \& Glukhov, V. V. (2018). The principles of organizing the educational system for personnel training in a digital economy. St. Petersburg State Polytechnical University Journal: Economics, 11(2), 7-16. 
Wesselink, R., Jong, C., \& Biemans, H.J.A. (2010). Aspects of competence-based education as footholdsto improve the connectivity between learning in school and in the workplace. Vocations and Learning, 3, 19-38.

Whiddett, S., \& Hollyforde, S. (2008). The competencies handbook. Jaico Publishing House: Mumbai, India, 206.

White, J., \& Dozier, D. M. (1992). Public relations and management decision making. Excellence in Public Relations and Communication Management/J. E. Grunig (Ed.), 1992, Hillsdale, NJ: Lawrence Erlbaum, 91 108.

World Development Report 2016: Digital Dividends. World bank (2016). Available at: https://openknowledge.worldbank.org/handle/10986/23347.

Zerfass, A., Verčič, D., Verhoeven, P., Moreno, A., \& Tench, R. (2015). European Communication Monitor 2015. Creating communication value through listening, messaging and measurement. Results of a Survey in 41 Countries. Brussels: EACD/ EUPRERA, Helios Media. Available at: http://www.communicationmonitor.eu/wp-content/uploads/2018/03/ECM-2015-Results-ChartVersionEuropean-Communication-Monitor-Trends-Strategic-Communication-Management-CorporateCommunication-Public-Relations-PR.pdf.

Zerfass, A., Buhmann, A., Tench, R., Verčič, D., \& Moreno, A. (2021). European Communication Monitor 2021. CommTech and digital infrastructure, video-conferencing, and future roles for communication professionals. Results of a survey in 46 countries. Brussels: EUPRERA/EACD. Available at: https://www.communicationmonitor.eu/2021/05/21/ecm-european-communication-monitor-2021/.

Zerfass, A., Moreno, A., Tench, R., Vercic, D., \& Verhoeven, P. (2017). European Communication Monitor 2017. How strategic communication deals with the challenges of visualisation, social bots and hypermodernity. Results of a survey in 50 countries. Brussels: EACD/EUPRERA, Quadriga Media Berlin. Available at: https://www.communicationmonitor.eu/2017/06/04/ecm-european-communication-monitor-2017-socialbots-visualisation-hypermodernity-benchmarking-strategic-communication/.

Zerfass, A., Moreno, A., Tench, R., Verčič, D., \& Verhoeven, P. (2008). European Communication Monitor 2008. Trends in Communication Management and Public Relations - Results and Implications. Brussels, Leipzig: Euprera/University of Leipzig. Available at: http://www.communicationmonitor.eu/wpcontent/uploads/2018/03/ECM-2008-Results-ChartVersion-European-Communication-Monitor-TrendsStrategic-Communication-Management-Corporate-Communication-Public-Relations-PR.pdf.

Zerfass, A., Moreno, A., Tench, R., Verčič, D., \& Verhoeven, P. (2009). European Communication Monitor 2009. Trends in Communication Managementand Public Relations - Results of a Survey in 34 Countries (Chart Version). Brussels: Euprera. Available at: http://www.communicationmonitor.eu/wpcontent/uploads/2018/03/ECM-2009-Results-ChartVersion-European-Communication-Monitor-TrendsStrategic-Communication-Management-Corporate-Communication-Public-Relations-PR.pdf.

Zerfass, A., Moreno, A., Tench, R., Verčič, D., \& Verhoeven, P. (2013). European Communication Monitor 2013. A Changing Landscape - Managing Crises, Digital Communication and CEO Positioning in Europe. Results of a Survey in 43 Countries. Brussels: EACD/EUPRERA, Helios Media. Available at: http://www.communicationmonitor.eu/wp-content/uploads/2018/03/ECM-2013-Results-ChartVersionEuropean-Communication-Monitor-Trends-Strategic-Communication-Management-CorporateCommunication-Public-Relations-PR.pdf.

Zerfass, A., Tench, R., Verčič, D., Verhoeven, P., \& Moreno, A. (2014). European Communication Monitor 2014. Excellence in Strategic Communication - Key Issues, Leadership, Gender and Mobile Media. Results of a Survey in 42 Countries. Brussels: EACD/EUPRERA, Helios Media. Retrieved from: http://www.communicationmonitor.eu/wp-content/uploads/2018/03/ECM-2014-Results-ChartVersionEuropean-Communication-Monitor-Trends-Strategic-Communication-Management-CorporateCommunication-Public-Relations-PR.pdf.

Zerfass, A., Tench, R., Verhoeven, P., Verčič, D., \& Moreno, A. (2018). European Communication Monitor 2018. Strategic communication and the challenges of fake news, trust, leadership, work stress and job satisfaction. Results of a survey in 48 Countries. Brussels: EACD/EUPRERA, Quadriga Media Berlin. Available at: https://www.communicationmonitor.eu/wp-content/uploads/dlm_uploads/ECM18-EuropeanCommunication-Monitor-2018.pdf.

Zerfass, A., Tench, R., Verhoeven, P., Verčič, D., \& Moreno, A. (2010). European Communication Monitor 2010. Status Quo and Challenges for Public Relations in Europe. Results of an Empirical Survey in 46 Countries (Chart Version). Brussels: EACD, EUPRERA. Available at: http://www.communicationmonitor.eu/wpcontent/uploads/2018/03/ECM-2010-Results-ChartVersion-European-Communication-Monitor-TrendsStrategic-Communication-Management-Corporate-Communication-Public-Relations-PR.pdf. 
Changes in communication management roles due to globalization:

A case of communication management competencies mapped by international professional public relations

associations (2015-2020)

Authors: Renata Matkevičiené, Lina Jakučionienè

Zerfass, A., Van Ruler, B., Rogojinaru, A., Verčič, D., \& Hamrefors, S. (2007). European Communication Monitor 2007. Trends in Communication Management and Public Relations - Results and Implications. Leipzig: University of Leipzig / Euprera. Available at: http://www.communicationmonitor.eu/wpcontent/uploads/2018/03/ECM-2007-Results-ChartVersion-European-Communication-Monitor-TrendsStrategic-Communication-Management-Corporate-Communication-Public-Relations-PR.pdf.

Zerfass, A., Verčič, D., Verhoeven, P., Moreno, A., \& Tench, R. (2019). European Communication Monitor 2019. Exploring trust in the profession, transparency, artificial intelligence and new content strategies. Results of a survey in 46 countries. Brussels: EUPRERA/ EACD Quadriga Media Berlin. Available at: http://www.communicationmonitor.eu/wp-content/uploads/dlm_uploads/ECM19-European-CommunicationMonitor-2019.pdf.

Zerfass, A., Verčič, D., Verhoeven, P., Moreno, A., \& Tench, R. (2012). European Communication Monitor 2012. Challenges and Competencies for Strategic Communication. Results of an Empirical Survey in 42 Countries. Brussels: EACD/EUPRERA. Available at: http://www.communicationmonitor.eu/wpcontent/uploads/2018/03/ECM-2012-Results-ChartVersion-European-Communication-Monitor-TrendsStrategic-Communication-Management-Corporate-Communication-Public-Relations-PR.pdf.

Zerfass, A., Verhoeven, P., Moreno, A., Tench, R., \& Verčič, D. (2020). European Communication Monitor 2020. Ethical challenges, gender issues, cyber security, and competence gaps in strategic communication results of a survey in 44 countries. Brussels: EUPRERA/EACD. Available at: https://www.communicationmonitor.eu/2020/05/29/ecm-european-communication-monitor-2020/.

Zerfass, A., Verhoeven, P., Moreno, A., Tench, R., \&Verčič, D. (2016). European Communication Monitor 2016. Exploring trends in big data, stakeholder engagement and strategic communication. Results of a survey in 43 Countries. Brussels: EACD/EUPRERA, Quadriga Media Berlin. Available at: http://www.communicationmonitor.eu/wp-content/uploads/2018/03/ECM-2016-Results-ChartVersionEuropean-Communication-Monitor-Trends-Strategic-Communication-Management-CorporateCommunication-Public-Relations-PR.pdf.

Zerfass, A., Verhoeven, P., Tench, R., Moreno, A., \& Verčič, D. (2011). European Communication Monitor 2011. Empirical Insights into Strategic Communication in Europe. Results of an Empirical Survey in 43 Countries (Chart Version). Brussels: EACD, EUPRERA. Retrieved from: http://www.communicationmonitor.eu/wpcontent/uploads/2018/03/ECM-2011-Results-ChartVersion-European-Communication-Monitor-TrendsStrategic-Communication-Management-Corporate-Communication-Public-Relations-PR.pdf. 